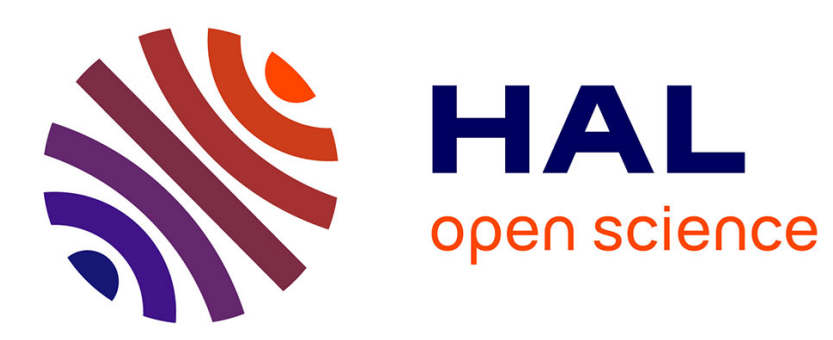

\title{
Serendipitous Outcomes in Space History: From Space Photography to Environmental Surveillance
}

\author{
Sebastian Grevsmühl
}

\section{To cite this version:}

Sebastian Grevsmühl. Serendipitous Outcomes in Space History: From Space Photography to Environmental Surveillance. Simone Turchetti; Peder Roberts. The Surveillance Imperative, Palgrave, pp.171-191, 2014, 978-1-349-49407-1. 10.1057/9781137438744_9. hal-01758343

\section{HAL Id: hal-01758343 \\ https://hal.science/hal-01758343}

Submitted on 12 Apr 2018

HAL is a multi-disciplinary open access archive for the deposit and dissemination of scientific research documents, whether they are published or not. The documents may come from teaching and research institutions in France or abroad, or from public or private research centers.
L'archive ouverte pluridisciplinaire HAL, est destinée au dépôt et à la diffusion de documents scientifiques de niveau recherche, publiés ou non, émanant des établissements d'enseignement et de recherche français ou étrangers, des laboratoires publics ou privés. 
This chapter was published in: Simone Turchetti and Peder Roberts (eds.), The Surveillance Imperative, New York: Palgrave, 2014, p.171-191

\title{
Chapter 8 \\ Serendipitous Outcomes in Space History: From Space Photography to Environmental Surveillance
}

\author{
Sebastian V. GREVSMÜHL
}

On February 8, 1962, the US Navy, in collaboration with the US Weather Bureau and the Canadian government, launched a major observation effort "to correlate observations of the ice conditions in the Gulf of St. Lawrence made from surface ships and aircraft with those made from the TIROS [Television Infrared Observation] satellite."1 Observation correlation in the context of satellite remote sensing meant two things. First of all, it implied learning how to look at the images provided by the first meteorological satellite program in order to use them in scientific studies. In order to make sense of the pictorial evidence, these images had to be correlated with other, better know "topographies of knowledge,"2 such as aerial photography, which had already become fully operational during World War I. Secondly, observation correlation required cooperation between major Cold War military and civilian organizations, such as the US Navy and the US Weather Bureau. Their participation thus reveals that these correlation studies had hidden surveillance ambitions and were sponsored not just in light of benefits to scientific knowledge but also because of a national security imperative.

Historians of twentieth-century science and technology have yet to fully explore the history of National Aeronautical and Space Administration's (NASA) satellite programs for environmental surveillance. Pamela Mack's pioneering study of the Landsat satellite project of the late 1960s and 1970s has shown that during the Cold War satellites enabled to gain an increasingly global picture of environmental conditions. Unfortunately, her research was not followed by many comparable in-depth studies. Probably one of the most notable exceptions is Erik Conway's Atmospheric Science at NASA and, to a lesser degree, Henry Lambright's NASA and the Environment: The Case of Ozone Depletion. ${ }^{3}$ By contrast, following Ron Doel's pioneering work, historians have covered the subject of military patronage of Cold War environmental sciences quite extensively. ${ }^{4}$ Some scholars have examined the surveillance implications of early space photography and satellite imagery. ${ }^{5}$ National Reconnaissance Office (NRO) historian Cargill Hall contributed particularly strongly to our current understanding of 
the close cooperation, yet also the severe tensions that existed between the NRO and the American space agency all along the Cold War period. ${ }^{6}$ Clandestine technology transfer from military to nominally civilian institutions was common practice in the United States during the Cold War, as John Cloud and Dwayne Day have shown. ${ }^{7}$

In this chapter I pay closer attention to the actual mediation processes involved in producing novel environmental knowledge. I examine how information was gathered and interpreted and how the conclusions were drawn. One lesson to be taken from the following reflections on early missile and satellite technologies is that from the very beginning NASA managed to attract the attention of very different communities to the usefulness of remote environmental observations. We also learn that remote sensing imaging proved to be a technology with a far wider range of applications than those their inventors had in mind. For instance, V-2 photographs were conceived to understand the motion of rockets along their trajectory, but they also quickly attracted the interest of geographers and especially meteorologists who began to use the images to gain a better understanding of environmental phenomena. In a quite similar way, images obtained with the first US meteorological satellite TIROS served civilian as well as military goals. They helped convey new information on cloud coverage and atmospheric systems that was of interest not only to meteorologists but also to military planners, allowing for better scheduling of photographic reconnaissance sorties. Moreover, in the absence of clouds, the satellite images themselves could potentially reveal sensitive terrain information such as snow and ice cover.

This chapter argues that the discovery that these images could be used differently from what they had been originally designed for was often "serendipitous." I also show that these novel applications of remote sensing imagery marked an important transition from their use in military research programs, devoted to improving weapons and surveillance of enemy forces, to their utility in "environmental surveillance" studies.

\section{Early Space Photography and Serendipity}

One of the most striking elements in early history of space photography is that at the outset its utility was somewhat narrowly defined and, eventually, its users gained new insights on its potential for the advancement of environmental analysis. At the time of the early postwar rocket flights, leading scientists from both sides of the Iron Curtain claimed that observation technologies were narrowly conceived for operational use and "photography was rarely the main purpose of a flight." 10 For example, early photographs obtained on V-2 flights during the late 1940s and early 1950s at the US Army Ordnance's White Sands Proving Ground in New Mexico were taken in order "to acquire a better knowledge of various motions executed by the missile in going through the upper atmosphere." 11 The realization was in other words the result of serendipity, as the rocket camera was not deliberately directed toward the Earth or its features so as to image them, but rather toward the rocket's trajectory in order to reveal its path during the flight.

Various other types of instruments and detectors were also flown to analyze other characteristics of the missile system and its interaction with the medium 
through which it travelled. These included devices to monitor the influence of cosmic rays, disruption to telecommunications due to rocket exhaust, and other effects due to the missile's discharge. ${ }^{12}$ As veritable flying laboratories, V-2 rockets and especially the so-called Aerobees (the first large vector for atmospheric research in the United States) were also fitted with detection devices and automatic recorders. Photographic equipment was in other words only one of many onboard sensors used to gather valuable data on the flight. However, when the routine rocket recording operations returned a wealth of numeric data and other material artifacts (including photographs), those scientists who had access to them realized that these could find application in other research fields. Rocket photographs showed important features of the Earth (including its curvature and jet streams) and could thus be reutilized in the context of meteorological research or in studies focusing on the whole Earth.

The success of V-2, Aerobee, and Viking photography is even more remarkable considering that most of those spectacular images were not only unexpected, but that missile experts attempted to fire the rockets during clear weather conditions, in order to prevent problems during the launch and ensure the safe reception of valuable information on the missiles' trajectory upon the vehicle's reentry. ${ }^{13}$ What the specialists working at White Sands initially considered a nuisance, that is, the presence of meteorological systems in proximity of the launching site, eventually enabled "the most spectacular use of photography in connection with rocket research." 14 Analysts of the RAND Corporation (the think tank with close ties to the US Air Force) were also well aware of the accidental nature of rocket photographs, and RAND's first feasibility study on meteorological satellites openly acknowledged that the new information on cloud formations were gained "from data which were not originally gathered for this purpose."15

Photographs were not the only outcome of an operational use that eventually found different applications. Spectrographs flown aboard V-2s in the context of Army Ordnance's 1946 rocket program are another good example. They excited not only astronomers interested in solar spectra but also meteorologists and geophysicists studying absorption processes in the upper atmosphere. Moreover, the first solar spectrogram captured above the ozone layer provoked even broad acclaim not only among specialists but also in the national and international press. ${ }^{16}$ Yet, as David DeVorkin has shown, it is important to mention that this considerable success did not rely at the time on the expertise of solar physicists or any of the leading researchers in atmospheric physics. It was Richard Tousey, a National Research Laboratory (NR L) specialist in laboratory optical techniques and the limits of vision, who designed the $\mathrm{V}-2$ spectrograph. In fact, the vast majority of US researchers engaged in upper atmosphere research were not part of "traditional" academic communities. Trained in military laboratories during World War II, these radio and radar engineers, technicians, and optics specialists aligned scientific research to a national security agenda by promoting novel research with the aim of improving defense systems. ${ }^{17}$

Tousey's instrument was in other words a component of science experiments that, while nominally civilian, were tightly aligned to the interests of the US armed forces in preparing for a nuclear conflict. Improving ballistic missile trajectories was an imperative in building up reliable missile systems, which was the ultimate guiding objective of all the $\mathrm{V}-2$ science experiments of the early 
Cold War. ${ }^{18}$ One major "side effect" was the considerable gain in environmental knowledge. Indeed, as Ron Doel has argued, it is certainly not an exaggeration to state that the guided missile helped tremendously to "constitute the physical environmental sciences in the US after 1945." 19

\section{The Mobilization of the First Space Photographs in the Context of Meteorological Research}

Rocket photography had a significant impact in the advancement of meteorology in the United States and helped its most prominent experts to experiment with photographic materials blending together a variety of different techniques. It also made them eager to promote new satellite programs for weather reconnaissance. Already by the end of the 1940s, the White Sands rocket program had produced spectacular photographs, including some showing the Earth's curvature and a variety of meteorological systems above our planet. Those pictures (disseminated also via the popular press, such as in National Geographic ${ }^{20}$ ) helped to promote rocket imagery well beyond military departments and to ensure space photography became adopted in the running of other scientific endeavors. ${ }^{21}$

The photographs seemed to have promise especially for meteorological research and stimulated plans to launch a satellite mainly devoted to taking images from space to know more about jet streams and other large-scale atmospheric phenomena and processes. ${ }^{22}$ Some NASA experts were wary of this solution due to the enormous complexity of the task ahead..$^{23}$ But others, such as the meteorologist Harry Wexler (the US Weather Bureau's observer on the panel overseeing the V-2 program at White Sands Proving Ground), were determined to push the scientific exploits to be derived from rocket experiments. Wexler was one of several US science administrators (also including Joseph Kaplan, Lloyd Berkner, James Van Allen, Homer Newell, and Fred Singer) who saw the development of a satellite as critical to the advancement of meteorology in the United States. ${ }^{24}$ Yet they succeeded only when US military agencies offered funding for the endeavor. This was mainly because of their interest in technologies that drastically improved surveillance and the planning of military operations by providing up-to-date meteorological information. Already a 1946 report by the RAND Corporation argued for the feasibility of satellites and noted unambiguously that "perhaps the two most important classes of observation which can be made from such a satellite are the spotting of the points of impacts of bombs launched by us, and the observation of weather conditions over enemy territory." 25

Aware that support existed for his plans, Wexler vigorously campaigned for a US weather satellite. In May 1954, he presented his views to a large audience gathered on occasion of the Third Symposium on Space Travel held at Hayden Planetarium (New York). For the first time Wexler's vision of a satellite Earth observation program emerged and he used numerous slides of photographs "accidentally" showing meteorological systems obtained with the cameras installed on the V-2. Two years later, he presented his ideas again at the Third Annual Conference of the American Astronautical Society. Besides a rather rudimentary photographic mosaic already used during his previous speech, Wexler now showed a remarkably sophisticated composite image, which Otto E. Berg of 
the Naval Research Laboratory (NR L) had pieced together with the help of 16-mm photographs obtained in October 1954 on one of the Aerobee-Hi rocket $\mathrm{f}$ lights (Figure 8.1). Made out of more than 100 color photographs, enlarged and mounted on a sphere, Berg's composite picture was indeed an impressive visual argument for the need of satellite-based synoptic weather observations. ${ }^{26}$

Yet the mosaic was a serendipitous outcome of NRL's missile program and nobody could anticipate that rocket photographs would be used for this purpose. Few also believed it possible to visualize for instance a tropical storm that, in fact, was now visible near the Gulf of Mexico in the upper left of the mosaic. Berg's photomontage clearly exemplified the enormous potential of satellite photography for meteorological analysis. This is also the reason why the article that Berg published together with Lester Hubert (US Weather Bureau) on the mosaic concluded that " $\mathrm{t}]$ he possibilities suggested by this accidental rocket reconnaissance of a tropical storm are tremendous." ${ }^{27}$ In September 1955 the popular press celebrated Berg's "portrait of the Earth" and a double color page was published in the magazine Life $^{28}$ The mosaic thus generated interests in satellite photography well beyond military circles. The serendipitous finding that clouds could be continuously photographed from space made Wexler even more enthusiastic. Presumably drawing on the parlance of military personnel reconnoitering Soviet forces, he now envisaged that a weather satellite could function as a "storm patrol." 29

The photographic mosaic, however, also demonstrated the advantages of combining different techniques of analysis of pictorial evidence consisting of composing images and then treating them with a variety of meteorological methods.

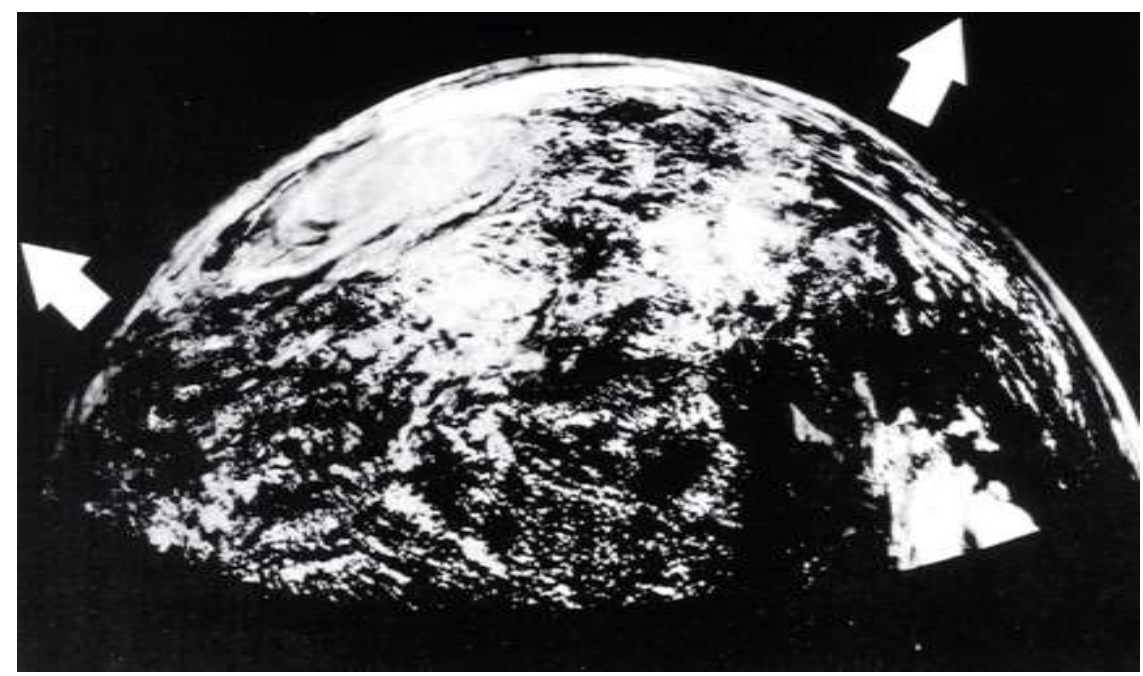

Figure 8.1 Black-and-white photomontage of more than 100 individual photographs obtained during a US Navy Aerobee flight in 1954 and mounted on a sphere by NR L scientist Otto Berg. A large whirlpool of cloud left over from a tropical cyclone above the Gulf of Mexico, discovered by chance, is visible in the upper left of the image Source: NOAA image library. 
The whole complexity of the synoptic weather situation, especially, as in the case of Berg's mosaic, due to the presence of several small vortices, proved to be undetectable when relying solely on the standard contour analysis traditionally employed in meteorology. Indeed, as Berg and Hubert point out in their article, three vortices were "sufficiently small to be overlooked in the routine contour analysis" as they were below "the detection threshold of [the] data network." 30 The data points that the meteorologists had at their disposal were in other words still too sparse in order to be able to draw contour lines allowing to reveal the three circular structures that were however clearly visible in Berg's mosaic. ${ }^{31}$

Rocket photographs revealed, in other words, a whole new complexity in the state of the atmosphere. They also helped visualize new weather systems and patterns such as for example cyclone structures that explained in Berg's case the actual cause of a local high-precipitation phenomenon, as normally known from the tropical regions, by simply visualizing their presence. ${ }^{32}$ Yet the photographs could not represent a goal in their own right. Many elements of the photographic mosaic could only be of utility if analyzed with traditional meteorological methods. Therefore, Berg's recent mosaic represented a good opportunity to correlate novel pictorial data with more traditional methods of meteorological analysis. The example clearly shows that each visualization medium possesses its own "epistemic limits" according to what I have called elsewhere an "epistemic topography." ${ }^{33}$ Rocket and satellite photographs were breaking new ground in meteorological work mainly because they enabled the observation of large-scale meteorological systems from above rather than below, allowing therefore a complete rethinking of the global atmospheric system.

The new epistemic topography called for a new visual language. ${ }^{34}$ In 1951 , two RAND analysts, Stanley M. Greenfield and William W. Kellogg, argued in a report for introducing a whole new method of cloud classification based on the visual appearance of clouds in pictorial evidence from rockets. They also stated that the new visual language ought to replace existing classification criteria, since observing clouds from above dramatically changes shapes and patterns and they often do not coincide with the traditional view from the ground. In other words, the inversion of perspective and the broader, synoptic viewpoint created fundamentally new knowledge that traditional classification schemes could not produce. ${ }^{35}$ Unsurprisingly, the most experienced scientists involved in V-2 photographic analysis concluded at the time that " $[\mathrm{t}]$ he manner in which clouds or a cloud formation seen from above and from below coincide is still far from being definitely known." 36

However, by combining different types of knowledge, by (often literally) superimposing traditional meteorological analysis and visualization of cloud cover, it slowly became possible to identify new large-scale phenomena and to correlate them with better-established local knowledge. ${ }^{37}$ Indeed, the example of cloud photography shows very well the necessity of integrating different kinds of epistemic topographies, which assisted in the development of meteorology all through the Cold War. ${ }^{38}$

By experimenting with rocket photographs and correlating visual data with other techniques Wexler, Berg, and other prominent US meteorologists could set a new agenda in meteorological studies in the United States, a rationale based on environmental surveillance. This was an agenda that, quite evidently, drew 
on existing Cold War challenges in terms of both method and instruments. Methodologically, it promoted reconnaissance as a useful way to attack weather analysis and in terms of instrumentation it advocated reusing equipment originally developed for military research purposes. Yet Wexler even envisioned the advantages to be derived from a satellite devoted to meteorology thanks to the assistance of a professional painter, as we shall now see.

\section{Harry Wexler and the Invention of a First Satellite Icon}

The integration of different topographies of knowledge in the field of meteorology was one of Harry Wexler's main objectives. Although enthusiastic about Berg's photographic mosaic, he was aware that rocket photography was far less effective than satellite photography. In the long run, only satellite observations of the atmosphere would allow a synoptic and continuous production of weather data. Wexler was also aware of the great power pictures could bear on funding institutions and decision makers. Indeed, as David DeVorkin noted, the offices of Wexler superior's were always "well adorned with photographs of storms and cloud systems taken from space." ${ }^{39}$ In 1954 he thus sought to commission a painting from an unknown artist who was "stimulated by such chance photos from research rockets." ${ }^{, 40}$ Also, Wexler was well placed to judge how impressive the natural power of meteorological phenomena could be. As a former member of the Meteorology Division in the Army Air Forces, in 1944 he actually flew across a hurricane that would later be famously called for its extreme violence the "Great Atlantic Hurricane."41

The painting ordered by Wexler shows a hypothetical view of parts of the Earth and its atmosphere at an altitude of about 6,400 kilometers above Amarillo, Texas. Due to its circular framing, some cultural historians have referred to the painting as a precursor of the famous blue marble. ${ }^{42}$ Yet an observer would have to travel at least double the distance Wexler had chosen for this hypothetical view of the Earth's atmosphere in order to see the curvature of planet Earth appear in the way that it was portrayed by the Apollo astronauts. ${ }^{43}$

The painting was realized with the support of numerous new scientific insights, as Wexler explained during his talk at the Third Symposium on Space Travel. On that occasion the painting acquired a new status as a "truly scientific image," even if its evident "constructed" character strikes the contemporary observer. ${ }^{44}$ Most of the depicted weather systems were quite "realistically" anticipated and showed a truly remarkable correspondence to high-altitude cloud photographs as data from TIROS and other programs would reveal a few years later. ${ }^{45}$

All the elements depicted were carefully elaborated on the canvas. For example, the continental parts of the painting are represented taking into account "reflectivity of sunlight" and the "scattering and depleting effects on the passage of light through the Earth's atmosphere."46 Furthermore, the image is dominated by very different kinds of clouds, ranging from "a cyclone family of three storms" to "a hurricane" and cloud streets, to which "albedo values were assigned [...] and their brightnesses [sic] computed." ${ }^{, 47}$ Yet the probability for each of these different cloud types to appear simultaneously was low: "the trade cumuli could undoubtedly be observed on almost any day and others, such as the hurricane, seen only rarely." 48 
The unknown artist, thanks to Wexler's guidance, was thus able to unite in one single picture the greatest possible number of different cloud types and produce a sort of condensed cloud "atlas." This explains Wexler's interest in this painting as it enabled to establish a veritable visual typology of Earth's "atmospheric systems" seen from space. Photographic naturalism, even if it had been at Wexler's disposition, would never have sufficed to reveal what Wexler wanted to show to his public. ${ }^{49}$ Moreover, the choice of a perpendicular perspectiveintroducing the theme of the planisphere ${ }^{50}$ - seems indispensable in underlining Wexler's intention to transform the sky illustrations into quantifiable and clearly identifiable scientific objects, reinforcing his message that these instruments ought soon to be built.

Throughout the 1950s and 1960s, scientists in the United States, but also the broad public, hoped that these new technologies would one day even allow efficient "weather control." 51 It comes therefore as no surprise that Wexler's innovative understanding of weather analysis and observation also relied on the support of military organizations to become reality. If NASA's TIROS program was conceived as a "storm patrol," 52 then it was also a means to a Cold War surveillance end, as we shall now see.

\section{Towards an Integration of Data: TIROS, the First Meteorological Satellite Program}

The earliest RAND report on meteorological satellite surveillance unambiguously stated that "in the event of armed conflict there will be large regions of the world from which it will be impossible to obtain weather information by normal means. Owing to the fact that the success of any aerial reconnaissance depends, to a large extent, on $[\ldots]$ knowledge of the weather conditions over the target, the lack of this information will be felt more and more as any planned air offensive progresses. Systematic weather reconnaissance by some unconventional means must therefore be undertaken.. ${ }^{53}$ When Wexler's plans were examined by prominent military agencies in the United States, what caught their attention was not the potential of space photography for meteorological research alone, but also for surveillance operations.

The integration of surveillance technologies, such as photographic and television cameras, into the satellite payload seemed to have promise in terms of boosting the capacity to reconnoiter enemy territories, and was therefore worth significant investments. As a consequence, the US Air Force and the US Army $f$ inanced research on different satellite observation technologies. ${ }^{54}$ If military objectives, such as improving the performance of rockets, gave leeway to developing important areas of civilian research, including the application of television and photography to meteorological programs, then these programs offered cover for furthering other military projects, including surveillance satellites. Even knowledge of cloud coverage in itself provided highly relevant intelligence information. It allowed for better coordination of traditional photographic reconnaissance flights, especially since cloud coverage posed a major threat to their successful accomplishment.

It therefore made sense, at least from the US perspective, to vigorously promote free access to space to improve the ability to reconnoiter enemy territories. 
The International Geophysical Year scientific satellite program provided therefore the historical and legal basis for what Cargill Hall rightly identif ied as "a stalking horse to establish the precedent of overflight in space for the eventual operation of military reconnaissance satellites." 55 Indeed, as Walter McDougall has shown and as Roger Launius argues in his contribution to this book, US presidents Dwight D. Eisenhower and John F. Kennedy clearly understood the multiple benefits to be derived from granting free access to outer space. Eisenhower's controversial "Open Skies" proposal and Kennedy's plea for "peaceful uses of outer space" both aimed to defuse any possible objections against satellite reconnaissance. ${ }^{56}$

In the field of meteorology, the official and well-known outcome of this strategy was the initiation under the Kennedy administration of discussions with the Soviet Union on a joint meteorological satellite program, united under the aegis of the World Meteorological Organization. Approved in 1963 as the World Weather Watch and still in operation today, the program, with its subsystems, coordinates meteorological observation efforts to provide weather services in all countries. ${ }^{57}$

However, the free access to space policy also served military reconnaissance and surveillance interests. Many scientific satellite programs, some similar to TIROS, offered cover for spy missions. For example, NASA's Discoverer program-officially announced to the public as a research program dedicated to examining and reporting on the space environment, including most notably biomedical experiments with mice and monkeys - carried as its main payload the $f$ irst US photoreconnaissance satellite camera system used as part of the highly classified CORONA program. ${ }^{58}$ Also, in the 1960 s meteorological research satellites were routinely used as cover for military surveillance. For instance, between 1962 and 1994 the US Air Force Defense Meteorological Satellite Program (DMSP) deployed a whole set of meteorological satellites, largely identical to their civil counterparts of the TIROS program. ${ }^{59}$

The TIROS meteorological satellites were themselves born out of a surveillance satellite program. TIROS had an immediate military precursor known as US Army project Janus that was initially conceived as a reconnaissance project developed for spying on Soviet territory. ${ }^{60}$ The imaging technology was based on a study from the Radio Corporation of America (RCA), a proposal initially presented to the US Air Force for their secret reconnaissance program known as WS-117L. After the bid was lost to Lockheed, RCA sold the idea to the Army where the work was developed further. Shortly after the NASA was created, the program (then known as Janus 2) was transferred in April 1959 to the Space Agency and renamed TIROS. Within the TIROS program, NASA obtained the overall responsibility for engineering and launch and the US Weather Bureau had to oversee operation and data interpretation. ${ }^{61}$

This transfer to nominally civilian institutions is generally considered the beginning of a clear separation of military and civilian programs. Yet the TIROS program shows that throughout the Cold War, this distinction is highly ambiguous, if not to say artificial. Indeed, a closer look at Cold War meteorology efforts erodes our confidence in the distinction between nominally military and nominally civilian uses. Despite important achievements of the DMSP, for example during the Cuban missile crisis in 1962, the Department of Defense also continued to make use of TIROS imagery. In fact, in order to fully assure DoD's 
need for an operational weather satellite, TIROS's two read-out sites at Fort Monmouth and on Hawaii were permanently staffed with "teams composed of meteorologists from the Weather Bureau and Department of Defense agencies" and a "Navy meteorologist was stationed at Ft. Monmouth during the entire operational period of TIROS I."62 For the same purpose, as documented by the agreement that officially transferred the program to NASA, a joint DoD-NASA advisory group was put in place and substantial DoD funding allocated to the program in order to assure full cooperation. ${ }^{63}$

In terms of technology, it is true that the TIROS meteorological satellites had relatively low-resolution central reconnaissance components because of the civilian use NASA was supposed to make of them. ${ }^{64}$ But TIROS's reduced resolution enabled more information to be gained than expected. Both satellite cameras produced black-and-white images composed of distinct lines, making the contrast of the vidicon images one of their most important criteria. ${ }^{65}$ The imaging technology was designed to better identify and visualize meteorological systems, but once the first satellite was operational other Earth features also became discernable.

This is a recurrent theme in the history of remote sensing: observation technologies produce a "surplus" of information, something not anticipated when they were designed. Following the reception of the first TIROS images, scientists started to become interested in phenomena that had little to do with meteorology. Some photographic mosaics portraying regions surrounding the Gulf of Saint Lawrence (Canada) showed numerous white spots on black background (Figure 8.2). More serendipitous discoveries were about to happen and

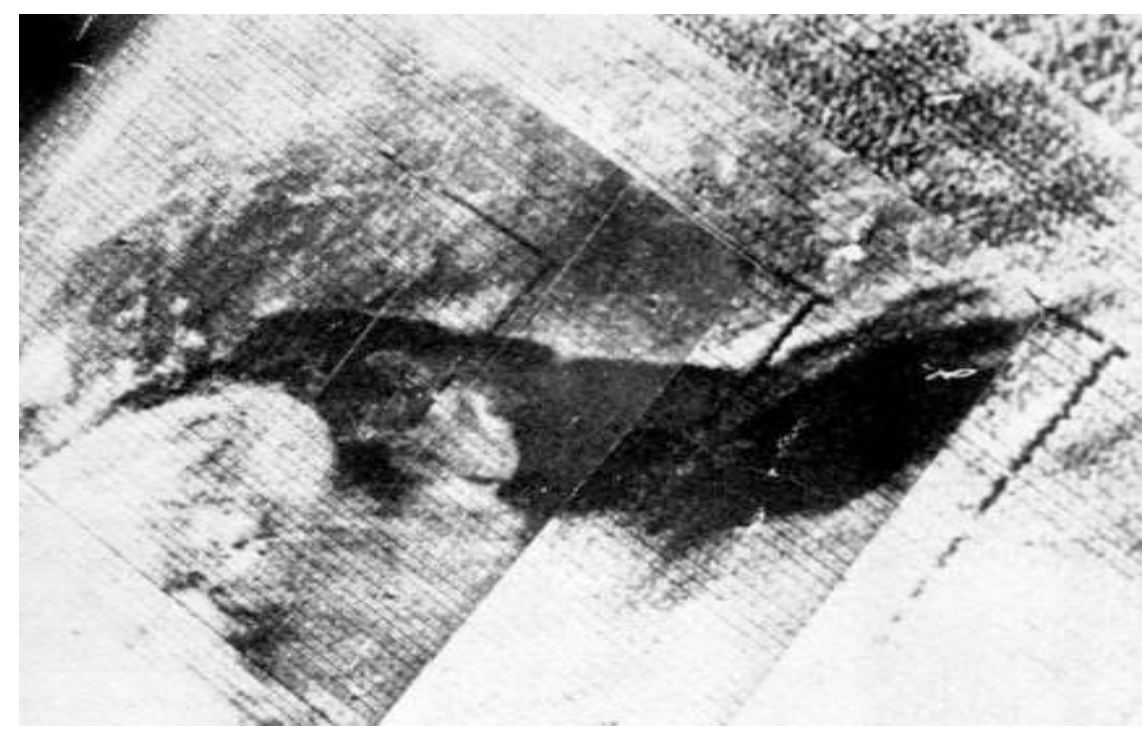

Figure 8.2 Composite image of oblique views taken from TIROS-I above the Gulf of Saint Lawrence on April 1, 1960. The image has enough contrast to allow distinguishing water, clouds and sea ice

Source: NOAA image library. 
Harry Wexler eventually concluded that those white spots could be sea ice. ${ }^{66}$ So in the 1960s, Wexler supervised a group of scientists at the US Weather Bureau that investigated in greater depth ice surveillance techniques-an application that touched upon, as I will show now, military, scientific, political, as well as economic questions. ${ }^{67}$

\section{TIREC: Environmental Satellite Surveillance during the Cold War}

The accidental reconnaissance of sea ice through a satellite designed to produce pictures of clouds eventually led to project TIR EC. Launched in 1962 project TIR EC aimed "to correlate observations of the ice conditions in the Gulf of Saint Lawrence made from surface ships and aircraft with those made from the TIROS satellite." 68 TIR EC, an acronym for TIROS Ice Reconnaissance, had as main objective the development of "procedures and techniques for interpreting satellite readouts of ice formation." "69 It was in many ways an unforeseen byproduct of the first American weather satellite program, a serendipitous application of remote cloud observation, initially not included in the list of possible weather satellite uses.

At the end of the first two experimental phases, TIR EC confirmed, even without a refined resolution, what Wexler had foreseen. It proved indeed possible to distinguish clouds from ice and to produce maps of sea ice. The comparison of images taken at different times as well as their geometric correction (for example, image distortion resulting from the lens of the camera had to be corrected) helped in achieving this task.

"Measurement of ice and snow cover," as a report to the US Congress in 1962 deliberately vaguely put it, had indeed "also [...] a military application.",70 Lavishly endowed with military funding, TIR EC eventually helped to more $f$ irmly establish environmental surveillance as a way to establish control over polar regions. Sea ice maps obtained through correlation of satellite data allowed for improved coordination of military and scientific logistics in the cold regions. They also granted otherwise unavailable information on access to strategic sites via polar transit areas. As one representative of the Canadian Defense Board noted, sea ice observations were especially important to identify places where submarines may emerge. ${ }^{71}$

Ice observations were also of "direct economic interest," a major motivation for putting TIR EC in place. ${ }^{72}$ In a study on the nonmeteorological uses of TIROS and the Nimbus satellite programs, Fred Singer (better known today for his global warming skeptic declarations ${ }^{73}$ ) argued that meteorological satellites could have saved Canadian and US administrations, for the year 1961 alone, no less than $\$ 1.7$ million traditionally put aside for logistical operations and the planning of navigable waterways, a figure geologist and geophysicist Paul Lowman of Goddard Space Flight Center rightly considered "misleadingly conservative" as further savings could be derived from using the same system in Western Europe, Russia, and especially Antarctica. ${ }^{74}$ TIROS data also offered invaluable support to the US Navy in Antarctic exploration and helped to strengthen its role as principal logistics operator at the South Pole. ${ }^{75}$ 
Climate scientists benefitted from satellite-based ice observations and correlation studies too. These proved decisive in establishing local temperature trends (most notably warming trends), as well as water circulation estimates, all factors that became important elements of modern climate change interpretations and predictions. ${ }^{76}$ For example, synoptic ice observations allowed revealing that the Antarctic continent doubles its size each winter, growing well beyond Europe's surface area by attaining about 34 million square kilometers thanks to the accumulation of sea ice. Indeed, from the 1960s onward, sea ice accumulation as inferred from satellite images has been routinely used to assess global climatic changes. ${ }^{77}$

Thus Project TIR EC pioneered Cold War environmental surveillance. The reasons behind its development were not just scientific. Economic, logistic, strategic, and geopolitical ambitions were equally relevant. ${ }^{78}$ Soon after Project TIR EC was established, a conference on satellite ice studies was held in Washington, DC. By looking at the agencies and institutions represented, one understands how important these studies had now become to civilian and military organizations alike. Representatives of Canada's Defence Research Board and its Joint Photographic Intelligence Center, together with the Royal Canadian Air Force were present. Among participants from the United States, the Weather Bureau, NASA, the Department of Transport, and the National Science Foundation (US Antarctic Program) had all sent delegates. Among the 51 participants, only four can be identif ied as coming from universities and not holding any official military accreditation. ${ }^{79}$ These numbers show very well that at the very beginning of satellite ice observations - they coincide practically with the very birth of the first meteorological satellite program-military concerns clearly went hand in hand with scientific and economic interests.

\section{Conclusion}

We should think of the example of space photography as shedding new light on how military patronage made it possible to realize the inner surveillance potential of a range of imaging technologies - a potential that was not foreseen when photographic cameras were first installed on rockets.

In order to understand the history of satellite imagery we need to reconsider the importance that accidental discoveries played in key moments of its unfolding. The use of satellite photography for meteorological purposes was the unintended outcome of attempts to monitor the path of ballistic missiles during their flight. The application of satellite cameras to monitor sea ice was also unforeseen, as photographs produced to "patrol" storms eventually captured more details than expected; including sea ice formations. Thus serendipity proved to be a crucial heuristic element in the contemporary analysis of earth features such as clouds and polar ice caps. Numerous case studies in history of science have shown the diverse ways in which instruments and technologies may $\mathrm{f}$ ind new uses, most notably through the exploitation, by chance, of some of their "hidden" characteristics and properties. Turchetti et al. went a step further and showed in their case study on radio echo-sounding in Antarctica that "when accidents and errors become the subject of scientific enquiry, they can instigate a broader analysis of the range of applications associated with the experimental apparatus in use and in turn favor its adoption more remotely from its cur- 
rent domain." 80 Project TIR EC similarly shows that beyond simple exploitation of hidden properties, systematic analysis of environmental surveillance imagery favored its adoption in other scientific domains.

Closely linked to this accidental discovery is the importance of material culture linked to the first meteorological satellite program at the beginning of the 1960s. The particularities of the visualization technology, most notably the poor resolution depending directly on the visual contrast, largely guided the use of satellite images. Within the context of the Cold War, this meant that a "civilian" observation technology, as soon as it aroused interest from the military, could more easily attract important funding, favoring the production of environmental knowledge with immediate utility for national security.

However, the adoption of the new remote sensing techniques that accidental $\mathrm{f}$ indings enabled required much more than just serendipity. The military sponsorship of new projects such as TIROS and TIR EC made it possible to realize what accidents had proven just as a possibility but needed substantial funding to show its real potential. This chapter has shown that support was given in light of the benef its to surveillance and military operations to be derived from satellite imagery. The synoptic view of the satellite could easily help decide whether aerial reconnaissance sorties over enemy territory would be efficient or not. Yet there was also a more generally added value of satellite photography in allowing assessments to be made about accessibility to sea ice covered areas, controlling navigable waterways and identifying regions which could be potentially used as hideout for enemy submersibles. So while the opportunity existed to explore what was serendipitously found through space photography, it was the Cold War urgency of improved surveillance that enabled to further explore the potential of these accidental discoveries. New knowledge of key earth features thus emerged in the search of more sophisticated methods to know about enemy forces.

Moreover the TIR EC project shows that NASA was also actively engaged in environmental surveillance and continued to pursue it for several years after TIR EC reached completion. For instance, photographs from the Mercury and Gemini space missions attracted great interest from a number of experts working on a number of different scientific disciplines. In particular, during the 1960s, geographers, geologists, and hydrologists took advantage of the new possibilities that remote sensing offered them and used space photography in a variety of projects favoring, for instance, a more systematic monitoring of natural resources. Oceanographers also prof ited from imagery produced during space programs, as in the case of TIROS, profiting from the growing spectrum of new technologies for environmental exploration and surveillance. ${ }^{81}$ Indeed, it is not an exaggeration to suggest that the interest that space photography generated was a decisive factor in the adoption of satellite-based environmental remote sensing techniques in the 1970s, including those aimed to more accurately ascertain the availability of natural resources and vital aspects of global environmental change. ${ }^{82}$

\section{Notes}

1. Abraham Schnapf, "The TIROS Global System," Annals of the New York Academy of Sciences 134 (1965): 149-166, citation 156.

2. Sebastian Vincent Grevsmühl, "Epistemische Topograf ien. Fotograf ische und radartechnische Wahrnehmungsräume," in Ingeborg Reichle, Steffen Siegel, 
Achim Spelten (eds.), Verwandte Bilder. Die Fragen der Bildwissenschaft (Berlin: Kadmos, 2007), 263-279.

3. Pamela E. Mack, Viewing the Earth: The Social Construction of the Landsat Satellite System (Cambridge, MA: MIT Press, 1990); Erik M. Conway, Atmospheric Science at NASA: A History (Baltimore: Johns Hopkins University Press, 2008); W. Henry Lambright, NASA and the Environment: The Case of Ozone Depletion (Washington, DC: NASA, 2005). See also: Pamela E. Mack and Ray A. Williamson, "Observing the Earth from Space," in John M. Logsdon (ed.), Exploring the Unknown: Selected Documents in the History of the U.S. Civil Space Program, Vol.III: Using Space (Washington, DC: NASA, 1998), 155-177; John H. McElroy and Ray A. Williamson, "The Evolution of Earth Science Research from Space: NASA's Earth Observing System," in John M. Logsdon, Stephen J. Garber, Roger D. Launius, and Ray A. Williamson (eds.), Exploring the Unknown: Selected Documents in the History of the U.S. Civil Space Program, Vol.VI: Space and Earth Science (Washington, DC: NASA, 2004), 441-473, and finally Erik M. Conway, "Drowning in Data: Satellite Oceanography and Information Overload in the Earth Sciences," Historical Studies in the Physical and Biological Sciences 37 (2006): 127-151.

4. See among others: Ronald E. Doel, "Constituting the Postwar Earth Sciences: The Military's Inf luence on the Environmental Sciences in the USA After 1945," Social Studies of Science 33 (2003): 635-666. See in the same issue: Kai-Henrik Barth, "The Politics of Seismology: Nuclear Testing, Arms Control and the Transformation of a Discipline," Social Studies of Science 33 (2003): 743-781. Jacob D. Hamblin, Oceanographers and the Cold War: The Disciples of Marine Science (Seattle: University of Washington Press, 2005); Jacob D. Hamblin, Arming Mother Nature: The Birth of Catastrophic Environmentalism (Oxford: Oxford University Press, 2013); John Cloud and Keith C. Clarke, "Through a Shutter Darkly: The Tangled Relationships Between Civilian, Military, and Intelligence Remote Sensing in the Early U.S. Space Program," in Judith Repps (ed.), Secrecy and Knowledge Production, Peace Studies Program Occasional Paper no. 23 (Ithaca: Cornell University, 1999), 36-56; John G. Cloud, "American Cartographic Transformations During the Cold War," Cartography and Geographic Information Science 29 (2002): 261-282; Simone Turchetti, Katrina Dean, Simon Naylor and Martin Siegert, "Accidents and Opportunities: A History of the Radio Echo-Sounding of Antarctica, 1958-79," British Journal of the History of Science 41 (2008): 417- 444.

5. I adopt here a common, although arbitrary definition of "space imagery," which postulates that any activity above 100 kilometers altitude may be considered an (outer) space activity. Early V-2 flights (launched around 1947) went beyond 100 kilometers altitude and may be counted therefore amongst the first space activity. For this common definition, see for example: Alain Dupas, La nouvelle conquête spatiale (Paris: Odile Jacob, 2010), 95.

6. See for example: R. Cargill Hall, A History of the Military Polar Orbiting Meteorological Satellite Program (Chantilly, VA: NRO Office of the Historian, 2001); R. Cargill Hall, "Origins of U.S. Space Policy: Eisenhower, Open Skies, and Freedom of Space," in John Logsdon et al. (eds.), Exploring the Unknown: Selected Documents in the History of the U.S. Civil Space Program, Vol.I: Organizing for Exploration (Washington, DC: NASA History Division, 1995), 213-229.

7. For example, NRO reconnaissance technology was secretly transferred to NASA's Lunar Orbiter program and the US Geological Survey acquired both CORONA photography and technologies to best use the photography for mapping purposes. See especially: John Cloud, Hidden in Plain Sight: CORONA and the Clandestine 
Geography of the Cold War, PhD diss. (Santa Barbara: University of California, 1999), 256 -264; R. Cargill Hall, SAMOS to the Moon: The Clandestine Transfer of Reconnaissance Technology Between Government Agencies (Chantilly, VA: NRO Office of the Historian, 2001); Dwayne A. Day, "Mapping the Dark Side of the World, Part 1: The KH-5 ARGON Geodetic Satellite," Spaceflight 40 (1998): 264 -269; Dwayne A. Day, "Mapping the Dark Side of the World, Part 2: Secret Geodetic Programmes After ARGON," Spaceflight 40 (1998): 303-310.

8. "Serendipity" refers to the process of accidental discovery in science. In many cases, research questions are oriented toward other goals and uses than those that the actual discovery reveals. See for example: Robert K. Merton and Elinor Barber, The Travels and Adventures of Serendipity: A Study in Sociological Semantics and the Sociology of Science (Princeton: Princeton University Press, 2004); Royston Roberts, Serendipity: Accidental Discoveries in Science (New York: Wiley, 1989).

9. The notion "environmental surveillance" refers to all observation, measurement, and detection technologies, which allow to describe on a more or less global-scale environmental phenomena.

10. See on this point: B.V. Vinogradov, "Kosmicheskaya fotograf iya dlya geogra- $f$ icheskogo izucheniya Zemli," Izvestiya Vsesoyuznogo Geograficheskogo Obshchestva 98 (1966): 101-111; translation (by NASA): B.V. Vinogradov, Space Photography for the Geographical Study of the Earth, NASA TT-F-10246 (Washington, DC: NASA, 1966). The citation is from the Anglo-Canadian geographer Brian Bird: J. Brian Bird and A. Morrison, "Space Photography and Its Geographical Applications," Geographical Review 54 (1964): 463-486, citation 468.

11. Thor Bergstralh, "Photography from the V-2 at Altitudes Ranging up to 160 Kilometers," in Homer E. Newell and Joseph W. Siry (eds.), Upper Atmosphere Research Report no. IV, NR L report R-3171 (Washington, DC: Naval Research Laboratory, 1947), 119-130, citation 119; Bergstralh's chapter is a reprint of a report that was published beforehand individually as NR L report R-3083, 1947.

12. David DeVorkin cites a large range of applications in his excellent book: David DeVorkin, Science with a Vengeance: How the Military Created the US Space Sciences After World War II (New York: Springer, 1992). A few NR L (Naval Research Laboratory) reports document also very well those efforts; one in particular will be discussed later.

13. A good overview is given by Homer Newell in his chapter on "High-altitude Photography," in Homer E. Newell, High Altitude Rocket Research (New York: Academy Press, 1953), 283-288, especially 283-284. See also: Robert Poole, Earthrise: How Man First Saw the Earth (New Haven, CT: Yale University Press, 2008), 64.

14. Newell, High Altitude Rocket Research, 283.

15. Stanley M. Greenf ield and William W. Kellogg, Inquiry Into the Feasibility of Weather Reconnaissance From a Satellite Vehicle, report no. R-365 (Santa Monica: RAND Corporation, 1951), 14.

16. The Washington Post reproduced two of the spectrograms on its front page of its October 30, 1946, issue. Other newspapers adopted enthusiastically the story, see: DeVorkin, Science with a Vengeance, 143-144.

17. DeVorkin, Science with a Vengeance, 1-6.

18. See: ibid., especially Chapter 9. See also: Ronald E. Doel, "Quelle place pour les sciences de l'environnement physique dans l'histoire environnementale," Revue d'histoire moderne et contemporaine 56 (2009): 137-164, here 149.

19. Ronald E. Doel, "Constituting the Postwar Earth Sciences: The Military's Influence on the Environmental Sciences in the USA After 1945," Social Studies of Science 33 (2003): 635-666, here 638. 
20. See: Ryan Edgington, "An 'All-seeing Flying Eye': V-2 Rockets and the Promises of Earth Photography," History and Technology 28 (2012): 363-371.

21. Meteorological analysis derived from rocket imagery, illustrated by V-2 photographs, was first suggested by USAF meteorologist D. L. Crowson, "Cloud Observations From Rockets," Bulletin of the American Meteorological Society (1949): 17-22.

22. Jet stream analysis became next to cyclone tracking one of the major application fields. For an example of visual jet stream analysis, see: US Navy, Weather Analysis from Satellite Observations (Norfolk: Navy Weather Research Facility, 1960), 30-31.

23. See: Pamela E. Mack and Ray A. Williamson, "Observing the Earth from Space," in Logsdon, Exploring the Unknown Vol.III, 155-177, here 156.

24. See on this point in more detail especially: Roger D. Launius, "What Are Turning Points in History, and What Were They for the Space Age?" in Steven J. Dick and Roger D. Launius (eds.), Societal Impact of Spaceflight (Washington, DC: NASA History Division, 2007), 19-39, here 31.

25. Douglas Aircraft Company, Preliminary Design of an Experimental WorldCircling Spaceship, report no. SM-11827 (Santa Monica: Douglas Aircraft Company, 1946), 11.

26. The original color photomontage is today part of the National Air and Space Museum collection, NASM object A19620042000. For a short description and black-and-white reproduction of the mosaic, see also: Edgar M. Cortright, Exploring Space with a Camera (Washington, DC: NASA, 1968), 4-5.

27. For a detailed description, see: Lester F. Hubert and Otto Berg, "A Rocket Portrait of a Tropical Storm," Monthly Weather Review 83 (1955): 119-124.

28. See: Anon., "A 100 Mile High Portrait of Earth," Life Magazine 39 (5 September 1955), $10-11$.

29. See: Harry Wexler, "Observing the Weather from a Satellite Vehicle," Journal of the British Interplanetary Society 7 (1954): 269-276, citation 269. The photographic mosaic also appeared in publications of the US Weather Bureau, promoting the use of satellite vehicles in meteorology. See for example: US Department of Commerce Weather Bureau, Meteorological Satellites - Global Weather Observers (Washington, DC: Department of Commerce, 1959).

30. Hubert and Berg, "A Rocket Portrait of a Tropical Storm," 122.

31. Contouring, in the atmospheric sciences jargon, means connecting data points of equal value. In general, contour analysis allows to understand how different geophysical variables change in time and space.

32. See: Hubert and Berg, "A Rocket Portrait of a Tropical Storm," 122.

33. The notion refers to the nature of instrumental logic which is proper to each visualization technology. Each visualization technology allows to see the world in a different way and it produces therefore knowledge that is specific to the instrumentation mobilized. See on this point in more detail: Grevsmühl, "Epistemische Topograf ien," 263-279.

34. Martin Rudwick was among the first historians who insisted on the importance of a common visual language in the making of a scientfic discipline, which was in his case geology around 1830, see: Martin Rudwick, "The Emergence of a Visual Language for Geological Science 1760 -1840," in Martin Rudwick (ed.), The New Science of Geology: Studies in the Earth Sciences in the Age of Revolution (Aldershot, Burlington: Ashgate, 2004 [1976]), 149-195.

35. Greenf ield and Kellogg, Inquiry Into the Feasibility of Weather Reconnaissance, 22. Richard Hamblyn has shown how Luke Howard introduce in England, in 1802, the vocabulary (which became general standard) to describe clouds mostly in function 
of their appearance - as seen from the ground - and altitude: Richard Hamblyn, The Invention of Clouds: How An Amateur Meteorologist Forged the Language of the Sky (London: Picador, 2001). However, a new descriptive section concerning specifically cloud classification as seen from above was included only in 1975 in the standard atlas meteorologist use. The photographic volume accompanying the $\mathrm{f}$ irst, descriptive volume took even longer to prepare-it appeared only in 1987: World Meteorological Organization, International Cloud Atlas: Manual on the Observation of Clouds and Other Meteors, WMO-no. 407, vol. 1 (text), vol. 2 (photographs) (Geneva: WMO, 1987 [1975]). Howard's classification system remains the main standard for small-scale phenomena. Leopold Kletter mentions some of the new cloud types which may only be observed from a satellite: Leopold Kletter, "Die praktische Auswertung der Bildsendungen der Wettersatelliten," Schriften des Vereins zur Verbreitung naturwissenschaftlicher Kenntnisse 110 (1970): 23-35.

36. This point is discussed in more detail, well before the launch of TIROS, in: William K. Widger and Chan N. Touart, "Utilization of Satellite Observations in Weather Analysis and Forecasting," Bulletin of the American Meteorological Society 38 (1957): 521-533.

37. For a typical example of a mosaic of TIROS photographs superimposed upon surface analysis and compared with conventional analysis, see: US Navy, Weather Analysis from Satellite Observations, 44.

38. The question of integration is for example discussed in more detail in a historical perspective in: Amy Dahan, "Putting the Earth System in a Numerical Box? The Evolution from Climate Modeling toward Global Change," Studies in History and Philosophy of Modern Physics 41 (2010): 282-292. Today, the high level of integration, which was put into place in climatology, meteorology's complementary discipline, is seen with quite some reticence.

39. DeVorkin, Science with a Vengeance, 145.

40. Harry Wexler, "The Satellite and Meteorology," Technical Session Preprints of the American Astronautical Society, Preprint no. 104254 (1956): 1-15, citation 8. On the painting, see especially the important work of Jim Fleming: James R. Fleming, "A 1954 Color Painting of Weather Systems as Viewed From a Future Satellite," Bulleting of the American Meteorological Society 88 (2007): 1525-1527; James R. Fleming, "Earth Observations from Space: Achievements, Challenges, and Realities," in Steven J. Dick (ed.), NASA's First Fifty Years: Historical Perspectives (Washington, DC: NASA History Division, 2010), 543-562, especially 548549; James R. Fleming, "Polar and Global Meteorology in the Career of Harry Wexler," in James R. Fleming, Roger D. Launius and David H. DeVorkin (eds.), Globalizing Polar Science: Reconsidering the International Polar and Geophysical Years (New York: Palgrave, 2010), 225-241, here 232. Wexler's color painting is also discussed in: P. Krishna Rao, Evolution of the Weather Satellite Program in the U.S. Department of Commerce-A Brief Outline, NOA A technical report NESDIS 101 (Washington, DC: Department of Commerce, NOA A, 2001), 8.

41. For biographical information on Wexler, I refer to Wexler's file in the archives of the International Geophysical Year: National Academy of Sciences, Archives of the IGY, "Series 13: IGY Personnel-Antarctic: Wexler, Harry, 1955-1957."

42. Alexander Linke and Dominique Rudin, "The Earth as Seen from Apollo 8 in Space," Rheinsprung 11: Zeitschrift für Bildkritik 1 (2011): 147-156.

43. Robert Poole traces this history in great detail in: Robert Poole, Earthrise: How Man First Saw the Earth (New Haven: Yale University Press, 2008).

44. See: Wexler, "Observing the Weather from a Satellite Vehicle," 269-276. The painting is reproduced as supporting document at the end of chapter 2 in: Logsdon, Exploring the Unknown Vol.III, 177-183. 
45. William K. Widger, "Satellite Meteorology_Fancy and Fact," Weather 16 (1961): $47-55$.

46. Wexler, "The Satellite and Meteorology," 10.

47. Ibid., 10 .

48. Ibid., 12 .

49. The scientific painting is therefore part of a larger historical development that may be observed all along the age of mechanical objectivity in which the principal function of the painting could only survive in scientific niches where classification and typology were indispensable; see: Peter Galison, "Judgment against Objectivity," in Caroline Jones and Peter Galison (eds.), Picturing Science, Producing Art (New York, London: Routledge, 1998), 327-359.

50. The term planisphere refers to the map-like view of the Earth as a result of the convergence of photography and flight during the ninteenth century, as put into pratice by early balloonists-photographers such as Nadar. The initial objective of Nadar's perpendicular photography was to elaborate maps, one of two common meanings of the term planisphere. See on this point in more detail: Sebastian Grevsmühl, La Terre vue d'en haut: l'invention de l'environnement global (Paris: Seuil, 2014); Sebastian Grevsmühl, A la recherche de l'environnement global: De l'Antarctique à l'Espace et retour, $\mathrm{PhD}$ thesis in history of science (Paris: Ecole des Hautes Etudes en Sciences Sociales, 2012), 240-243.

51. Weather control was until the early 1970 s a central theme in meteorology, see for example: Jacob Hamblin, Arming Mother Nature: The Birth of Catastrophic Environmentalism (New York: Oxford University Press, 2013); James R. Fleming, Fixing the Sky. The Checkered History of Weather and Climate Control (New York: Columbia University Press, 2010); Chunglin Kwa, "The Rise and Fall of Weather Modif ication: Changes in American Attitudes toward Technology, Nature, and Society," in Clark A. Miller and Paul N. Edwards (eds.), Changing the Atmosphere: Expert Knowledge and Environmental Governance (Cambridge, MA: MIT Press, 2001), 135-165.

52. Wexler, "Observing the Weather from a Satellite Vehicle," 269. Especially TIROS-III, launched during the US hurrican season, would acquire that reputation: Leopold Kletter, "Meteorologische Satelliten erforschen das Weltwetter," Schriften des Vereins zur Verbreitung naturwissenschaftlicher Kenntnisse 103 (1963): 1-17, here 7.

53. Greenf ield and Kellogg, Inquiry Into the Feasibility of Weather Reconnaissance, 1. See also: Hall, A History of the Military Polar Orbiting Meteorological Satellite Program as well as: Stephen B. Johnson, "The Political Economy of Spaceflight," in Steven J. Dick and Roger D. Launius (eds.), Societal Impact of Spaceflight (Washington, DC: NASA History Division, 2007), 141-191, especially 171.

54. Merton E. Davies and William R. Harris, RAND's Role in the Evolution of Balloon and Satellite Observation Systems and Related U.S. Space Technology, RAND report R-3692-RC (Santa Monica: RAND Corporation, 1988), 23. A detailed description of the historical dynamics between government bodies and the different military members can be found in: Hall, "Origins of U.S. Space Policy," 213-229. See also: Dwayne A. Day, "Invitation to Struggle: The History of Civilian-Military Relations in Space," in John M. Logsdon (ed.), Exploring the Unknown: Selected Documents in the History of the U.S. Civilian Space Program. Vol.II: External Relationships, NASA SP-4407 (Washington, DC: NASA, 1996), 233-270.

55. Hall, "Origins of U.S. Space Policy," 222.

56. Walter A. McDougall, The Heavens and the Earth: A Political History of the Space Age (New York: Basic Books, 1985), 117-118, 349-352. See also: Paul N. 
Edwards, "Meteorology as Infrastructural Globalism," Osiris 21 (2006), 229250 , especially 245 . See also Launius in this collection.

57. For a brief historical overview on World Weather Watch, see: James R. Rasmussen, "Historical Development of the World Weather Watch," WMO Bulletin 52 (2003): 16-25.

58. CORONA was the codename of the first US photoreconnaissance satellite system that successfully returned during a period of twelve years $(1960-1972)$ a large number of film capsules that were collected midair by specially equipped cargo planes and subsequently developed and interpreted by a USAF and CIA personnel. For a concise overview, see: David C. Arnold, "Corona," in Stephen B. Johnson (ed.), Space Exploration and Humanity: A Historical Encyclopedia, vol. 2 (Santa Barbara: ABC-CLIO, 2010), 873-875. See also: Dwayne A. Day, "The Development and Improvement of the CORONA Satellite," in Dwayne A. Day, John M. Logsdon and Brian Latell (eds.), Eye in the Sky: The Story of the Corona Spy Satellites, (Washington, DC: Smithsonian Institution Press, 1998), 48-85, here 53. Many now declassified records relating to the CORONA program and other formerly secret US photoreconnaissance programs may be accessed on the NRO website: http://www.nro.gov/FOIA/declass/index.html.

59. For a concise overview, see: James C. Mesco, "Defense Meteorological Satellite Program," in Johnson, Space Exploration and Humanity, vol. 2, 873-875.

60. See: Davies and Harris, RAND's Role in the Evolution of Balloon and Satellite Observation Systems, 25; Day, "Invitation to Struggle," 243 and 246.

61. See: NASA, TIROS: The System and its Evolution, NASA technical report NASATM-X-56696 (Washington, DC: NASA, 1965), 4. For an overview, see: David Leverington et al., "Tiros," in Johnson, Space Exploration and Humanity, vol. 1, $360-363$.

62. US Navy, Weather Analysis from Satellite Observations, 32.

63. Report to Congress from the President of the United States January 1, to December 31, 1959, p. 26. See the DoD-NASA agreement in: John M. Logsdon (ed.), Exploring the Unknown, Vol. III: Using Space, 203-204.

64. RCA deliberately downgraded the TIROS resolution for the simplified civilian version, see: Richard Leroy Chapman, A Case Study of the United States Weather Satellite Program: The Interaction of Science and Politics, $\mathrm{PhD}$ thesis in political sciences (Syracuse: Syracuse University, 1967); cited in Conway, Atmospheric Science at NASA, 27. Information conf irmed in: NASA, TIROS: The System and its Evolution, 7.

65. For a more detailed technical description, see the explanation of the TIROS I television system in the NSSDC Master Catalog: http://nssdc.gsfc.nasa.gov /nmc/experimentDisplay.do?id=1960-002B-01 (accessed October 24, 2013). In the case of TIROS the term satellite photography can be misleading. The TIROS imaging system was not based on photography but on vidicon tubes. The vidicon images were relayed to one of the two ground stations where they were visualized on a TV-screen that was eventually photographed by a $35 \mathrm{~mm}$ camera.

66. See the contribution of Robert Popham of the US Weather Bureau to the first conference on sea ice: Maurice D. Baliles and Herbert Neiss (eds.), Conference on Satellite Ice Studies, Meteorological Satellite Laboratory report no. 20 (Washington, DC: US Weather Bureau, 1963), 23.

67. For the first sea ice report, see: David Q. Wark and Robert W. Popham, "Tiros I Observations of Ice in the Gulf of St. Lawrence," Monthly Weather Review 88 (1960): 182-186. For an analysis of the first scientific advances in this young domain, see: David Q. Wark and Robert W. Popham, "The Development of Satellite Ice Surveillance Techniques," in Harry Wexler and James E. Caskey 
(eds.), Proceedings of the First International Symposium on Rocket and Satellite Meteorology (Amsterdam: North-Holland, 1963), 415-418.

68. Schnapf, "The TIROS Global System," 156.

69. NASA, Astronautical and Aeronautical Events of 1962: Report of the National Aeronautics and Space Administration to the Committee on Science and Astronautics, U.S. House of Representatives, Eighty-eighth Congress, First Session (Washington, DC: Government Printing Office, 1963), 14.

70. Library of Congress, Meteorological Satellites, Staff Report Prepared for the Use of the Committee on Aeronautical and Space Sciences United States Senate, Eightyseventh Congress, Second Session (Washington, DC: Government Printing Office, 1962), 39.

71. As in many other cases, the production of reliable maps demanded nevertheless the mobilization of traditional aerial reconnaissance. See the report: Defense Research Board, Project TIREC, February-April 1962, Preliminary report by the Canadian Participating Agencies, Canada, Defense Research Board, Directorate of Physical Research (Geophysics), Report No. Misc. G-11, February 1963. A similar argument is made in the following study: Baliles and Neiss, Conference on Satellite Ice Studies, 90.

72. Baliles and Neiss, Conference on Satellite Ice Studies, 26.

73. Before becoming climate change skeptic, Fred Singer fought other highly ambiguous ideological battles, such as the acid rain debate, the ozone depletion controversy as well as health dangers associated to passive smoking, defending mostly a position contradicting general scientific consensus, see: Naomi Oreskes and Erik M. Conway, Merchants of Doubt (New York: Bloomsbury Press, 2010). See also: Naomi Oreskes and Erik M. Conway, "Challenging Knowledge: How Climate Science Became a Victim of the Cold War," in Robert N. Proctor and Londa Schiebinger (eds.), Agnotology: The Making and Unmaking of Ignorance (Stanford: Stanford University Press, 2008), 55-89.

74. S. Fred Singer and Robert W. Popham, "Non-meteorological Observations from Weather Satellites," Aeronautics and Aerospace Engineering, 1 (1963): 89-92; Paul D. Lowman, A Review of Photography of the Earth from Sounding Rockets and Satellites, NASA TN D-1868 (Washington, DC: NASA, 1964), 18.

75. From 1961 onward, satellite data played for the US Navy a major role in the planning of Antarctic logistics, see: NASA Space Applications Program Office, $A$ Survey of Space Applications, NASA SP-142 (Washington, D.C.: NASA, 1967), 90; Alan T. Waterman, "New Horizons for the Atmospheric Sciences," Annals of the New York Academy of Sciences, 95 (1961): 688-696, especially 689. See also: Radio Corporation of America, TIROS: A Story of Achievement, AED P-5167A (Princeton: RCA, February 1964).

76. See for a telling example: David W. J. Thompson and Susan Solomon, "Interpretation of Recent Southern Hemisphere Climate Change," Science 269 (2002): 895-899.

77. One may note that law theorists also have analyzed this phenomenon since sea ice makes it extremely difficult to establish continental limits and territorial extension into the sea: Christopher C. Joyner, Antarctica and the Law of the Sea (Dordrecht: Martinus Nijhoff, 1992), 14-16. "Sea ice" is therefore, at least from a law viewpoint, an object incredibly difficult to define.

78. TIR EC was therefore a key source of environmental information in relation to Cold War concerns in fields like geophysics, seismology, oceanography, cartography and glaciology.

79. See the list of participants in: Baliles and Neiss, Conference on Satellite Ice Studies, iv-vi. 
80. Turchetti et al., "Accidents and Opportunities," 419.

81. For the large spectrum of applications developed in oceanography from the very beginning of the Space Age, see the conference report: Gifford C. Ewing (ed.), Oceanography from Space, Proceedings of the Conference on the Feasibility of Conducting Oceanographic Explorations from Aircraft, Manned Orbital and Lunar Laboratories. Held August 24-28 at Woods Hole, Massachusetts, USA, ref. no.65-10 (Woods Hole: Woods Hole Oceanographic Institution, 1965). For two examples of very specific uses outside of the initial application context, see: Alastair Morrison and M. Christine Chown, Photography of the Western Sahara Desert from the Mercury MA-4 Spacecraft, NASA Contractor report CR-126 (Montreal: Quebec, 1964); Paul M. Merifield and James Rammelkamp, Terrain in Tiros Pictures, contract no. NAS 5-3390, LR 17848 (Burbank: LockheedCalifornia Company, 1964). On scientific applications of photographs of the Gemini program, see for example: Paul D. Lowman, James A. McDivitt, and Edward H. White, Terrain Photography on the Gemini IV Mission: Preliminary Report, NASA Technical Note D-3982 (Washington, DC: NASA, 1967).

82. See the contribution of two representative of the US Geological Survey: William A. Fischer and Charles J. Robinove, "A Rationale for a General Purpose Earth Resources Observation Satellite," in Proceedings of University of Washington Remote Sensing Symposium (Washington, DC: Washington University, 1968), 36. 